\title{
Pediatric anterior larynx: presentations and associations
}

\author{
Hussein Smaily ${ }^{1}$, Ismaeel El-Hakim ${ }^{1}$, and Hamdy El-Hakim ${ }^{1}$ \\ ${ }^{1}$ University of Alberta
}

September 25, 2021

\begin{abstract}
Objective: The literature on the entity of the anterior larynx (AL) is restricted to little evidence on the difficulty encountered in exposing the larynx for intubation, perioperative morbidity and mortality, and scant reports on its prevalence in general adults and children. We here describe the prevalence of AL in a series of children presenting with aerodigestive symptoms and explore its association with functional abnormalities, congenital and structural anomalies or conditions. Setting: Tertiary pediatric center Methods: we conducted a retrospective case-control study. Using a prospectively collected surgical database we identified patients diagnosed with AL (grades IIb-III-IV Modified Cormack-Lehane scale) and sex and age-matched controls who had undergone full airway endoscopy for aerodigestive symptoms. We collected the demographics, presentations, associated diagnoses, and investigations. We compared the proportion of patients with large airway abnormalities and dysmorphism and estimated the prevalence of AL. Results: over a 5.5-year period, 58 children ( 28 females) were matched with 58 controls. Although both groups presented with permutations of stridor, respiratory failure, cyanotic spells, swallowing and feeding difficulties and SDB, AL presented much more with swallowing and feeding problems (33 vs 20, p<0.05). There were significantly more children with dysmorphism in the AL group (29 vs $9, \mathrm{P}<0.05)$. The prevalence of AL was $4.9 \%$. Conclusions: This is the first study to report the prevalence of $\mathrm{AL}$ amongst a cohort of children with aerodigestive symptoms. Its significant association with dysmorphic features warrants genetic consultation. It is associated with swallowing abnormalities that justifies a systematic instrumental evaluation
\end{abstract}

\section{Hosted file}

Pediatric Anterior Larynx final draft w:o tables.docx available at https://authorea.com/ users/435980/articles/538636-pediatric-anterior-larynx-presentations-and-associations

Hosted file

Table 1.docx available at https://authorea.com/users/435980/articles/538636-pediatricanterior-larynx-presentations-and-associations

\section{Hosted file}

Table 2.docx available at https://authorea.com/users/435980/articles/538636-pediatricanterior-larynx-presentations-and-associations

\section{Hosted file}

Table 3.docx available at https://authorea.com/users/435980/articles/538636-pediatricanterior-larynx-presentations-and-associations

\section{Hosted file}

Table 4.docx available at https://authorea.com/users/435980/articles/538636-pediatricanterior-larynx-presentations-and-associations

\section{Hosted file}


Table 5.docx available at https://authorea.com/users/435980/articles/538636-pediatricanterior-larynx-presentations-and-associations

\section{Hosted file}

Table 6.docx available at https://authorea.com/users/435980/articles/538636-pediatricanterior-larynx-presentations-and-associations 